P-ISSN: 2774-4574; E-ISSN: 2774-4582

TRILOGI, 2(3), September-Desember 2021 (252-258)

@2021 Lembaga Penerbitan, Penelitian, dan Pengabdian kepada Masyarakat (LP3M) Universitas Nurul Jadid Paiton Probolinggo

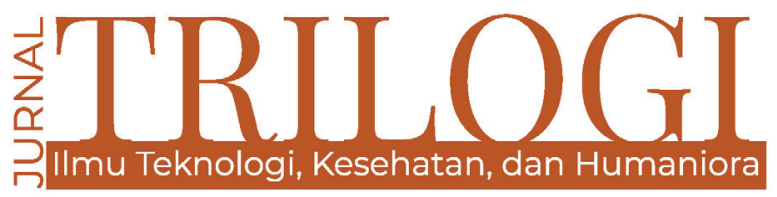

\title{
EFEKTIVITAS PERATURAN DAERAH NOMOR O3 TAHUN 2012 TENTANG PENGELOLAAN SAMPAH DI KABUPATEN PROBOLINGGO TERKAIT KESADARAN MASYARAKAT DALAM PENGEMBANGAN BANK SAMPAH
}

\section{Fatimah Al Zahra}

Universitas Nurul Jadid

iza.fhub@gmail.com

\section{Fitria Wulandari}

Universitas Nurul Jadid

fitriawulandari448@gmail.com
Muflahatul Hasanah

Universitas Nurul Jadid

muflah.cahaya@gmaail.com

Nur Hasanah

Universitas Nurul Jadid

nhs.ana99@gmail.com

\begin{abstract}
The increasing population lead to an increase in the volume, type, and characteristics of waste. Waste has become a global problem so that its management needs to be carried out in a comprehensive and integrated manner from upstream to downstream. A little mistakes in waste management will have an impact on environmental pollution and even lead to natural disasters. This research is a study related to its special environmental management regarding community empowerment through the development of waste bank in Probolinggo city. This research uses normative emphirical research. The normative emphirical research is a combination of normative legal approach with the addition of various empirical elements. Due to this research is related to community empowerment in developing garbage bank in managing environment. Subjects in this study are regulatory regulations relating to environmental management, especially the management of waste bank in the Probolinggo city. In this study, the object is the Local Regulation number 03 of 2013 on Waste Management. From the results of the study concluded that Regional Regulation number 03 of 2013 on waste management in the Probolinggo city has provided fresh wind to the development of waste bank in Probolinggo city which is also warmly welcomed by the Probolinggo city society to be aware of hygiene by changing the paradigm of society by gathering, transport, waste. Now the paradigm is transformed into saving innovation through waste bank by reusing existing waste with 3R (Reduce, Reuse, Recycle) Program.
\end{abstract}

Keywords: Effectiveness, Management, Waste Bank 


\begin{abstract}
Abstrak
Jumlah penduduk yang meningkat secara otomatis akan menambah volume, jenis, dan karakteristik sampah. Sampah telah menjadi permasalahan global sehingga pengelolaannya perlu dilakukan secara komprehensif dan terpadu dari hulu ke helir. Kekeliruan dalam pengelolaan sampah akan berdampak pada pencemaran lingkungan bahkan mengakibatkan terjadinya bencana alam. Penelitian ini berfokus pada pengelolaan lingkungan hidup, khususnya mengenai pemberdayaan masyarakat melalui pengembangan bank sampah di Kabupaten Probolinggo. Penelitian ini menggunakan metode penelitian yuridis empris yang merupakan penggabungan antara pendekatan hukum normatif dengan adanya penambahan berbagai unsur empiris. Pendekatan yuridis empiris ini dipilih karena penelitian ini berkaitan dengan pemberdayaan masyarakat dalam pengembangan bank sampah dalam mengelola lingkungan. Objek kajian dalam penelitian ini adalah Peraturan Daerah Nomor 03 Tahun 2012 tentang Pengelolaan Sampah. Dari hasil penelitian disimpulkan bahwa Peraturan Daerah Nomor 03 Tahun 2012 tentang Pengelolaan Sampah telah memberikan angin segar terhadap pengembangan bank sampah di Kabupaten Probolinggo yang juga disambut hangat oleh masyarakat Kabupaten Probolinggo untuk sadar akan kebersihan dengan merubah paradigma masyarakat tentang kumpul, angkut, buang. Kini paradigma itu berubah menjadi inovasi baru melalui bank sampah dengan cara memanfaatkan kembali sampah yang ada dengan Program 3R (Reduce, Reuse, Recycle).
\end{abstract}

Kata Kunci: Efektivitas, Pengelolaan, Bank Sampah.

\section{Pendahuluan}

Bertambahnya penduduk dan perubahan pola konsumsi masyarakat menimbulkan bertambahnya volume, jenis, dan karakteristik sampah yang semakin beragam. Badan Perencanaan Pembangunan Nasional (Bappenas) dan Badan Pusat Statistik (BPS) memperkirakan jumlah penduduk Indonesia pada tahun 2035 akan mencapai 305,65 juta pada tahun 2035, dan 75 persen tinggal di perkotaan. Kondisi ini menuntut para pemangku kepentingan untuk membuat kebijakan tata ruang dan pengelolaan lingkungan hidup yang baik. Sampah telah menjadi permasalahan nasional sehingga pengelolaannya perlu dilakukan secara komprehensif dan terpadu dari hulu ke hilir, sehingga dalam pengelolaan sampah ini diperlukan kepastian hukum, kejelasan tanggung jawab dan kewenangan pemerintah, serta peran serta masyarakat. Sinergitas para stake holder dalam upaya pengelolaan sampah dapat menjamin berjalannya proses pengelolaan sampah yang profesional, efektif, dan efisien.

Kekeliruan dalam pengelolaan sampah akan berdampak pada pencemaran lingkungan. Pelestarian lingkungan hidup berada pada peringkat ke-4 dalam 10 tantangan masa depan, sehingga harus mendapat perhatian serius. Pemerintah melalui Undang-Undang Nomor 18 Tahun 2008 tentang Pengelolaan Sampah berusaha secara serius untuk mengurai, mengantisipasi, dan mengurangi persoalan sampah tersebut (Sondang P, 2003:28). Selama ini masyarakat, pada umumnya melakukan pengelolaan sampah melalui proses pengumpulan, pengangkutan, dan pembuangan ke tempat pembuangan akhir sampah (TPA). Kenyataannya, masyarakat memiliki volume sampah yang besar dan apabila diangkut secara bersamaan justru akan menimbulkan pembusukan yang jelas akan merugikan kebersihan lingkungan dan udara. Kondisi ini berdampak pada menipisnya lapizan ozon dan timbulnya pemanasan global.

Pasal 3 UU Nomor 18 Tahun 2008 tentang Pengelolaan sampah menyebutkan bahwa: "Pengelolaan sampah diselenggarakan berdasarkan asas tanggung jawab, asas berkelanjutan, asas manfaat, asas keadilan, asas kesadaran, asas kebersamaan, asas keselamatan, asas keamanan, dan asas nilai ekonomi." Pasal 3 tersebut diperkuat dengan bunyi Pasal 35 Ayat (1) Peraturan Pemerintah Nomor 81 Tahun 2012 Tentang Pengelolaan Sampah yang menyebutkan bahwa: "masyarakat berperan serta dalam proses pengambilan keputusan, penyelenggaraan, dan pengawasan dalam kegiatan pengelolaan sampah rumah tangga dan sampah sejenis rumah tangga yang diselenggarakan oleh Pemerintah dan/ atau Pemerintah Daerah." Berdasarkan bunyi kedua pasal tersebut, dapat ditarik kesimpulan bahwa sampah harus dikelola berdasarkan pada kesadaran pemerintah dan juga keterlibatan maysarakat. Peran aktif masyarakat dalam pengelolaan sampah sangat dibutuhkan untuk 
meningkatkan kesehatan bagi masyarakat dan kualitas lingkungan serta menjadikan sampah sebagai sumber daya.

Kabupaten Probolinggo merupakan salah satu kabupaten yang berada di Provinsi Jawa Timur, tepat pada posisi $112^{\prime} 50^{\prime}-113^{\prime} 30^{\prime}$ Bujur Timur (BT) dan 7'40' - 8'10' Lintang Selatan (LS), dengan luas wilayah sekitar $169.616,65 \mathrm{Ha}$ atau $+1.696,17 \mathrm{~km} 2(1,07 \%$ dari luas daratan dan lautan Propinsi Jawa Timur) dan jumlah penduduk sebanyak 1.138.000.000 jiwa yang tersebar di 24 kecamatan, 5 kelurahan, dan 325 desa (https:// probolinggokab.go.id/kondisi-geografis/, diakses pada 26 Juli 2021). Dari jumlah penduduk yang sebanyak itu, sampah yang terdata di Dinas Lingkungan Hidup Kabupaten Probolinggo per harinya bisa mencapai ratusan ton. Jika sekianbanyak sampah tersebut tidak dapat dikelola dengan baik, jelas berbagai masalah pencemaran terhadap lingkungan akan muncul.

Setiap individu diprediksi dapat menghasilkan sampah (langsung maupun tidak langsung) minimal sekitar 0,5 kg per harinya. Sampah yang berasal dari pusat keramaian dan permukiman dari 24 kecamatan se-Kabupaten Probolinggo dibuang di Tempat Pembuangan Akhir (TPA) Seboro Kecamatan Krejengan yang mana hal ini membuat anggaran BBM membengkak. Melihat luasnya wilayah Kabupaten Probolinggo, sebaiknya harus ada 2 TPA di Kabupaten Probolinggo ini, 1 di barat dan 1 lagi di timur (Dwijoko Nurjayadi, 2021). Manajemen lokasi TPA ini merupakan salah satu penghambat dalam pengelolaan sampah di Kabupaten Probolinggo yang harus segera dicarikan solusinya.

Sebagaimana diberitakan dalam harian jawa pos, di bulan Agustus 2021 terdata ada 196,87 ha kawasan kumuh di Kabupaten Probolinggo yang tersebar di 33 desa pada 13 kecamatan, antara lain Kecamatan Kraksaan, Kecamatan Gending, Kecamatan Gading, Kecamatan Dringu, Kecamatan Kotaanyar, Kecamatan Krejengan, Kecamatan Leces, Kecamatan Paiton, Kecamatan Pajarakan, Kecamatan Sumberasih, Kecamatan Wonomerto, Kecamatan Maron, dan Kecamatan Besuk (https://radarbromo.jawapos.com/ kraksaan/24/08/2021/13-kecamatan-di-kabprobolinggo-masuk-kawasan-kumuh/, diakses pada 30 Agustus 2021). Kondisi ini menunjukkan bahwa pengelolaan sampah di Kabupaten Probolinggo belum maksimal. Perlu adanya sinergi antara Pemerintah Kabupaten Probolinggo dengan masyarakat untuk membenahi carut marutnya pengelolaan sampah di Kabupaten Probolinggo ini.
Mekanisme pengelolaan sampah di Kabupaten Probolinggo dilaksanakan berdasarkan apa yang tertuang dalam Peraturan Daerah Nomor 03 Tahun 2012 tentang Pengelolaan Sampah. Perda tersebut diundangkan dengan tujuan untuk meningkatkan akses pelayanan persampahan bagi masyarakat. Pelayanan persampahan yang maksimal nantinya diharapkan dapat meningkatkan kesehatan masyarakat dan kualitas lingkungan tempat tinggal. Selain itu, pelayanan pengelolaan sampah ini juga diharapkan dapat menjadi sumber penghasilan bagi masyarakat. Kesadaran masyarakat akan pentingnya pengelolaan sampah dengan prinsip Reduce, Reuse dan Recycle (3R) masih rendah, mayoritas masyarakat memandang sampah sebagai sesuatu yang harus dijauhi dan dimusnahkan dengan cara dibuang, dipindahkan dan dimusnahkan. Kondisi seperti ini jelas berimplikasi negatif terhadap produksi sampah harian, volume sampah terus meningkat dan menimbulkan penumpukan sampah yang kontinue di TPA Seboro Kecamatan Krejengan. Keterlibatan masyarakat untuk berperan serta dalam menghentikan persoalan sampah merupakan salah satu solusi yang dapat ditempuh untuk memutus rantai penumpukan sampah di TPA. Kegiatan membangun partisapasi masyarakat berhubungan dengan memberdayakan masyarakat serta mengembangkannya, karena di samping memerangi permasalahan sampah dan kebersihan lingkungan, juga mendorong masyarakat menjadi lebih aktif dan penuh inisiatif. (Sunyoto Usman, 2006:29)

Kesadaran masyarakat dalam menginisiasi pendirian beberapa bank sampah di Kabupaten Probolinggo adalah suatu upaya yang harus selalu dipupuk dengan cara memberikan edukasi secara massif kepada masyarakat. Edukasi perlu dilakukan secara gencar untuk merubah budaya atau kultur mayoritas masyarakat yang selama ini masih seringkali menumpuk, membakar, dan membuang sampah ke saluran irigasi. Jika kebiasaan atau budaya buruk tersebut tidak diubah, maka bisa berdampak buruk pada aspek kesehatan, iklim, serta nilai estetika wilayah Kabupaten Probolinggo.

\section{Metode}

Penelitian ini merupakan penelitian yuridis empiris dengan mengkaji data-data primer, sekundur, dan tersier yang diperoleh oleh peneliti. Metode yang digunakan dalam penelitian ini adalah deskritif kualitatif. Model pendekatan 
yang digunakan dalam penelitian ini adalah pendekatan yuridis sosiologis, yakni metode pendekatan yang dilakukan untuk mendapatkan data primer dan menemukan kebenaran dengan menggunakan metode berpikir induktif. Adapun kriteria kebenaran koresponden serta fakta yang digunakan untuk melakukan proses induksi dan pengujian kebenaran terhadap koresponden adalah fakta yang mutakhir (Soejono Soekanto dan Sri Mamuji, 2001:14).

Cara kerja dari metode yuridis sosiologis dalam penelitian ini, yaitu dari hasil pengumpulan dan penemuan data, serta informasi yang didapatkan melalui studi kepustakaan terhadap asumsi atau anggapan dasar yang dipergunakan dalam menjawab permasalahan, kemudian dilakukan pengujian secara induktif-verifikatif pada fakta mutakhir yang ditemukan oleh peneliti di lapangan. Untuk mengetahui fakta di lapangan, peneliti mengambil sample salah satu bank sampah yang ada di Desa Kedungsari, Kecamatan Maron, yakni Bank Sampah Barokallah yang pendiriannya diinisiasi sendiri oleh masyarakat setempat, sehingga partisipasinya lebih murni berawal dan dikembangkan oleh warga. Sampai akhir tahun 2020, sudah ada 20 bank sampah di bawah pembinaan Dinas Lingkungan Hidup Kabupaten Probolinggo, dan sekitar 15 bank sampah yang dikelola oleh masyarakat dan sekolah. Sedangkan sampah yang terambil per hari mencapai $15 \%$ dari total sampah yang dihasilkan masyarakat setempat.

\section{Pembahasan}

Menurut Undang-Undang Nomor 18 Tahun 2008 tentang Pengelolaan Sampah, yang dimaksud dengan sampah adalah adalah sisa kegiatan sehari-hari manusia dan/atau proses alam yang berbentuk padat. Sampah yang merupakan sisa dari kegiatan manusia harus dikelola agar tidak menimbulkan pencemaran lingkungan dan gangguan kesehatan. Pengelolaan sampah adalah kegiatan yang sistematis, menyeluruh, dan berkesinambungan yang meliputi pengurangan dan penanganan sampah. Pengurangan sampah yang dimaksud dalam Undang-Undang Nomor 18 Tahun 2008 tentang Pengelolaan Sampah meliputi kegiatan pembatasan timbulan sampah, pendauran ulang sampah, dan pemanfaatan kembali. Pengolahan sampah adalah kegiatan penanganan sampah mulai dari sumber atau timbulnya sampah hingga musnah atau habis, termasuk kegiatan ikutan lainnya seperti reduce (pengurangan volume atau jumlahnya), reuse (penggunaan kembali), recycle (daur ulang atau mengubah wujud dan bentuknya untuk pemanfaatan lainnya).

Pengelolaan sampah yang baik bukan saja untuk kepentingan kesehatan, tetapi juga untuk keindahan lingkungan. Pengelolaan sampah meliputi pengumpulan, pengangkutan sampai dengan pemusnahan atau pengolahan sampah sedemikian rupa sehingga tidak mengganggu kesehatan masyarakat dan lingkungan hidup. Beberapa permasalahan yang timbul dalam sistem penanganan sampah yang terjadi selama ini, antara lain (Dwijoko Nurjayadi, 2020):

1. Efisiensi yang rendah, karena sampah belum dipilah-pilah, sehingga kalaupun akan diterapkan teknologi lanjutan berupa komposting maupun daur ulang perlu tenaga untuk pemilahan menurut jenisnya, maka memerlukan dana besar maupun menyita waktu.

2. Pembuangan akhir ke TPA dapat menimbulkan masalah, membutuhkan lahan yang luas.

3. Menjadi lahan yang subur bagi pembiakan jenis-jenis bakteri serta bibit penyakit yang pada akhirnya akan mengurangi nilai estetika dan keindahan lingkungan.

Pergeseran pola pengelolaan persampahan perlu dilakukan seperti Pola Transformasi Waste to Source dan perlu dikembangkan sehingga sampah yang saat ini kita anggap sebagai sesuatu yang tidak berguna akan menjadi sesuatu yang memiliki nilai guna yang tinggi. Jika pengelolaan sampah ini melibatkan partisipasi masyarakat lewat pengembangan Bank Sampah, diharapkan bukan hanya berdampak pada terlaksananya Peraturan Daerah Nomor 03 Tahun 2012 tentang Pengelolaan Sampah, tetapi juga bisa merubah cara pandang masyarakat terhadap sampah yang salah. Selama ini sampah dipandang sebagai sesuatu yang harus dijauhi karena tidak bisa mendatangkan manfaat, Perda ini diharapkan dapat menyadarkan masyarakat bahwa sampah merupakan sesuatu yang memiliki nilai ekonomis.

Definisi dari bank sampah sendiri dapat ditelusuri dari arti kata per kata sebagai berikut. Bank adalah badan usaha yang menghimpun dana dari masyarakat dalam bentuk simpanan dan menyalurkannya kepada masyarakat dalam bentuk kredit dan/ atau bentuk-bentuk lainnya untuk meningkatkan taraf hidup rakyat banyak (Ismaya Surjana, 2006:34). Sedangkan sampah menurut kamus istilah lingkungan, sampah adalah 
bahan yang tidak mempunyai nilai atau tidak berharga untuk maksud biasa atau utama dalam pembuatan atau pemakaian barang rusak atau bercacat dalam pembuatan materi berkelebihan atau ditolak atau buangan (Suwerda Bambang, 2012: 9). Jadi, bank sampah bisa dipahami sebagai suatu tempat penghimpun sampah baik sampah organik maupun non-organik dengan melalui suatu proses sehingga menjadi barang yang bernilai ekonomis. Bank sampah adalah suatu tempat dimana terjadi kegiatan pelayanan terhadap penabung sampah yang dilakukan oleh teller bank sampah. (Suwerda Bambang, 2012: 22)

Bank sampah menerima tabungan berupa sampah tetapi dapat kembali dalam bentuk uang sehingga mampu mengubah image sampah yang notabennya negatif menjelma menjadi barang bernilai ekonomis. Perubahan nilai dari sampah ini tidak lepas dari sistem kerja yang diterapkan bank sampah. Perubahan yang dilakukan bank sampah tidak seutuhnya karena faktor ekonomi saja, melainkan peningkatan kesadaran lingkungan terhadap masyarakat. Proses penyadaran lingkungan melalui tabungan sampah yang dikonversi menjadi tabungan uang ini diharapkan dapat mengubah paradigma masyarakat tentang sampah.

Secara umum, sampah dapat diklasifikasikan menjadi 2 kelompok, yaitu sampah organik dan sampah anorganik. Sampah organik adalah sampah yang berasal dari makhluk hidup, misalnya sisa makanan, kulit buah-buahan, dan daun-daunan. Sampah anorganik, misalnya kaleng minuman, kaca, logam, keramik, plastik. Intensitas pencemaran sampah anorganik ini sangat tinggi dan selanjutnya menimbulkan kerugian untuk masyarakat. Sampah dapat bermanfaat jika dimanfaatkan dengan baik dan merugikan jika dibiarkan tanpa ada pengelolaan yang baik. Dampak negatif dari pengelolaan sampah yang tidak tepat akan menyebabkan beberapa kerugian, di antaranya pencemaran udara, air, dan tanah.

Pengelolaan sampah yang baik dapat dilakukan dengan cara daur ulang, daur ulang adalah penggunaan kembali material/ barang yang sudah tidak terpakai untuk menjadi produk lain. Langkah-langkahnya adalah pemisahan dengan cara memisahkan barang/ material yang dapat didaur ulang dengan sampah yang harus dibuang ke penimbunan sampah. Pastikan barang/ material tersebut kosong dan akan lebih baik jika dalam keadaan bersih. Penyimpanan barang/ material kering yang sudah dipisahkan tadi dilakukan dengan cara dimasukkan ke dalam boks/ kotak tertutup tergantung jenis barangnya, misalnya boks untuk kertas bekas, botol bekas, dll. Pengiriman/ penjualan, barang/ material yang terkumpul dijual ke pabrik yang membuthukan material tersebut sebagai bahan baku atau dijual.

Salah satu bank sampah yang pendiriannya diinisiasi dan dikembangkan sendiri oleh masyarakat adalah Bank Sampah Barokallah yang terletak di Desa Kedungsari, Kecamatan Maron. Bank Sampah Barokallah ini dikelola oleh beberapa anak muda, di antaranya: Tarensa Putera, Saifuddin, Ridlwan, Arif Rahman Hakim, Eko Budiyanto, Irfan Wahyudi dan Erwin Sutejo, serta dibina oleh beberapa civitas akademika dari beberapa kampus yang ada di Kabupaten Probolinggo. Sampai akhir tahun 2020, sudah ada 20 bank sampah di bawah pembinaan Dinas Lingkungan Hidup Kabupaten Probolinggo, dan sekitar 15 bank sampah yang dikelola oleh masyarakat dan sekolah. Setiap harinya, bank sampah dapat mengambil sekitar $15 \%$ dari total sampah yang dihasilkan oleh masyarakat setempat. Sampah-sampah yang dikumpulkan di bank sampah tersebut sebagian dibuat kerajinan, sebagian ada yang dipress, sebagian lagi diolah ulang menjadi biji plastik untuk dijual ke industri.

Selain menggalakkan bank sampah, Pemerintah Kabupaten Probolinggo juga mengajak warganya untuk mengolah sampah organik menjadi biogas. Biogas ini telah diterapkan di Desa Krejengan Kabupaten Probolinggo dengan kapasitas 4.800-6.700 kkal per meter kubik. Energi listrik yang dihasilkan dari instalasi tersebut dimanfaatkan untuk 10 hingga 15 rumah atau Kepala Keluarga. Bentuk partisipasi masyarakat dalam hal ini didasari atas keinginan yang kuat untuk melihat daerahnya bersih, rapi, dan sehat.

Berdasarkan pengamatan di lapangan, terdapat beberapa bentuk partisipasi masyarakat dalam pengelolaan sampah, antara lain:

1. Memilah sampah, pemilahan ini dilakukan oleh masyarakat sendiri dengan menyediakan 2 tempat sampah yang berbeda, 1 untuk sampah organic dan 1 lagi untuk sampah anorganik. Adapun sampah anorganik langsung disetorkan ke bank sampah untuk ditabung.

2. Melakukan daur ulang sampah organik menjadi pupuk kompos dan biogas. Pupuk hasil olahan dari sampah organik tersebut sebagian dijual dan sebagian lagi untuk pupuk tanaman warga setempat. Sedangkan 
biogas dimanfaatkan untuk penyediaan aliran listrik bagi rumah-rumah warga yang kurang mampu.

3. Pembuatan biopori yang berfungsi untuk resapan air, hal ini berguna untuk mempercepat meresapnya air ke dalam tanah sehingga dapat terhindar dari bencana banjir.

Pengelolaan sampah melalui program bank sampah yang dilakukan oleh Pemerintah Kabupaten Probolinggo ini tidak terlepas dari beberapa faktor pendukung dan faktor penghambat. Faktor pendukung dalam pengembangan bank sampah ini, antara lain:

1. Peran aktif Pemerintah Kabupaten Probolinggo, khususnya Dinas Lingkungan Hidup Kabupaten Probolinggo sebagai pendukung pelaksanaan program bank sampah telah dilakukan secara maksimal melalui upaya edukasi masyarakat dengan cara mengadakan sosialisasi, pelatihan, serta studi tiru ke kota/ kabupaten lain yang dianggap telah berhasil merealisasikan program bank sampahnya. Studi tiru ini baru sekali dilaksanakan, yakni pada hari Minggu 7 Maret 2021 ke TOSS Center di Dusun Karangdadi, Desa Kusamba, Kecamatan Dawan, Kabupaten Klungkung.

2. Peran aktif beberapa perusahaan yang bertempat kedudukan di Kabupaten Probolinggo untuk ikut menyukseskan program bank sampah dalam bentuk CSR (Corporate Social Responsibility), sampai saat ini ada 1 perusahaan yang bersinergi dengan Dinas Lingkungan Hidup Kabupaten Probolinggo dalam komitmen mensukseskan program bank sampah di Kabupaten Probolinggo ini, yakni PT POMI Paiton Energy.

Sedangkan faktor penghambat dalam program bank sampah ini, antara lain:

1. Kesadaran sebagian masyarakat terkait pentingnya pengelolaan sampah masih rendah, oleh karena itu Dinas Lingkungan Hidup Kabupaten Probolinggo perlu terus mengedukasi masyarakat untuk menyadarkannya.

2. Minimnya anggaran untuk kegiatan bank sampah, padahal proses pelatihan dan pengawasan bank sampah membutuhkan anggaran yang cukup besar, sehingga membutuhkan anggaran tetap setiap tahun dari berbagai pihak, baik dari pemerintah maupun swasta.
3. Harga sampah yang rendah, namun hal ini dapat disiasati dengan cara meningkatkan kreatifitas pengelola bank sampah sehingga dapat menghasilkan luaran produk yang berharga dan bernilai jual tinggi

4. Persaingan dengan para pengumpul sampah (bos rongsokan) yang memiliki modal lebih besar.

\section{Penutup}

Pengembangan bank sampah di Kabupaten Probolinggo dilaksanakan sesuai dengan amanat Undang-Undang Nomor 18 Tahun 2008 tentang Pengelolaan Sampah, Peraturan Pemerintah Nomor 81 tahun 2012 tentang Pengelolaan Sampah Rumah Tangga dan Sampah Sejenis Sampah Rumah Tangga, Peraturan Menteri Negara Lingkungan Hidup Republik Indonesia Nomor 13 Tahun 2012 Tentang Pedoman Pelaksanaan Reduce, Reuse, dan Recycle Melalui Bank Sampah, serta Peraturan Daerah Kabupaten Probolinggo Nomor 3 Tahun 2012 tentang Pengelolaan Sampah, keseluruhan aturan tersebut sebagai payung hukum yang diharapkan dapat merubah cara pandang masyarakat tentang pengelolaan sampah dan urgensi keberadaan bank sampah.

Bank sampah di Kabupaten Probolinggo dapat terus berkembang jika ada dukungan maksimal dari masyarakat selaku produsen sampah. Partisipasi nyata yang diharapkan dari masyarakat berupa kedisiplinan dalam pemilahan sampah rumah tangga berupa organik maupun anorganik, yang dilaksanakan oleh masyarakat itu sendiri. Sampah yang telah dipilah secara baik akan lebih mudah untuk diproses ke tahapan selanjutnya, untuk sampah anorganik bisa langsung ditabungkan ke bank sampah, sedangkan sampah organic bisa diproses menjadi pupuk alami ataupun biogas.

Pelaksanaan pengelolaan sampah melalui program bank sampah di Kabupaten Probolinggo ini tidak terlepas dari beberapa faktor pendukung dan faktor penghambat. Faktor pendukung dalam pengembangan bank sampah adalah peran serta Pemerintah Kabupaten Probolinggo sebagai pendukung pelaksanaan program bank sampah yang dilakukan melalui upaya edukasi masyarakat. Sedangkan untuk faktor penghambat ada beberapa poin, antara lain adalah: (a) kesadaran sebagian masyarakat yang masih rendah, (b) minimnya anggaran untuk kegiatan bank sampah, padahal proses pelatihan dan pengawasan bank sampah membutuhkan anggaran yang cukup 
besar, sehingga membutuhkan anggaran tetap setiap tahun dari berbagai pihak, baik dari pemerintah maupun swasta, (c) harga jual sampah yang rendah, (d) adanya persaingan dengan para pengumpul sampah yang bermodal lebih besar.

\section{Daftar Pustaka}

\section{Buku}

Sujana, Ismaya. (2006). Kamus Perbankkan. Bandung: Pustaka Grafika.

Soekanto, Soerjono. (1981). Pengantar Penelitian Hukum, Jakarta: Universitas Indonesia.

Soekanto, Soerjono \& Mamudji, Sri. (2001). Penelitian Hukum Normatif (Suatu Tinjauan Singkat). Jakarta: Rajawali Pers.

Siagian, Sondang P. (2003). Administrasi Pembangunan: Konsep, Dimensi, dan Strateginya. Jakarta: Bumi Aksara.

Usman, Sunyoto. (2006). Pembangunan dan Perbedayaan Masyarakat. Yogyakarta: Pustaka Pelajar Offset.

Bambang, Suwerda. (2012). Bank Sampah: Kajian Teori dan Penerapan. Yogyakarta: Pustaka Rihama.

Slamet, Y. (1994). Pembangunan Masyarakat Berwawasan Partisipasi. Surakarta: Sebelas Maret University Press.

\section{Peraturan Perundang-Undangan}

Undang Undang Negara Kesatuan Republik Indonesia Nomor 18 Tahun 2008 tentang Pengelolaan Sampah.

Peraturan Pemerintah Nomor 81 Tahun 2012 tentang Pengelolaan Sampah Rumah Tangga dan Sampah Sejenis Sampah Rumah Tangga.

Peraturan Menteri Negara Lingkungan Hidup Republik Indonesia Nomor 13 Tahun 2012 Tentang Pedoman Pelaksanaan Reduce, Reuse, dan Recycle Melalui Bank Sampah

Peraturan Daerah Kabupaten Probolinggo Nomor 3 Tahun 2012 Tentang Pengelolaan Sampah. 